\title{
The Attitudes of Future Educational Agents to Religious and Cultural Diversity in Education in Catalonia ${ }^{1}$
}

\author{
Ruth Vilà ${ }^{2}$ \\ M. José Rubio ${ }^{3}$ \\ Assumpta Aneas ${ }^{4}$
}

\begin{abstract}
The religious diversity in Catalonia is a challenge for the coexistence in the public space and for the education of future educators. This article emphasizes the challenge of religious diversity in the educational context, analyzing which attitudes have the educational agents of the future towards: a) the religious diversity, b) the interreligious and intercultural dialogue, and c) the role of education in the management of this diversity. In order to ask these questions have been conducted a survey study on the framework of the Project AGAUR-2014RELIG00019 named "Attitudes towards religious and cultural diversity in education for intercultural dialogue and interfaith scale". The population of the study has been the students in Teacher Training in Primary and Early Childhood, Social Education, Social Work and Pedagogy degree of all Catalan Public Universities. The conclusions highlight a) the favorable attitude towards cultural and religious diversity and interreligious dialogue and b) the relevance to the education given by the students, as a key role in the management of religious and cultural diversity.
\end{abstract}

Keywords: Religious diversity, Interreligious Dialogue, Higher Education, Teachers and Training Education, Pedagogy, Social Work, Social Education.

\section{Introduction}

Currently, in the Catalan context the diverse cultural reality also entails a map of diverse religious expressions. This reality is a challenge for coexistence in the public space and, at the same time, a challenge for education and future educators. The phenomena of the radicalism, xenophobia or fundamentalism are mostly articulated around the religious identity so this is an important responsibility the education and qualification of the socio educational agents about the interreligious relation in our societies.

In Catalonia, religious diversity is not a recent phenomenon. Around more than one hundred years ago were implanted the first Protestant, as well the Jews and Jehovah's testimonies communities (Estruch, 2014). What has happened is that the religious diversity has ceased to be invisible becoming a visible presence in public space. This diversity has been accelerated and increased by the migratory flows of the

1 This study was presented at the Education, Society, and Reform Research (EDUSREF 2018) between 6-7 April 2018 in Ankara,Turkey

2 Universitat de Barcelona, ruth_vila[at]ub.edu

3 Universitat de Barcelona, mjrubio[at]ub.du

4 Universitat de Barcelona, aaneas[at]ub.edu 
Africa, Asia, Eastern Europe and Latin America which their diverse religious background.

In order to understand approximately the distribution of these different confessions are useful the data related to the Coulters Center in Catalonia (Generalitat de Catalunya, 2016)

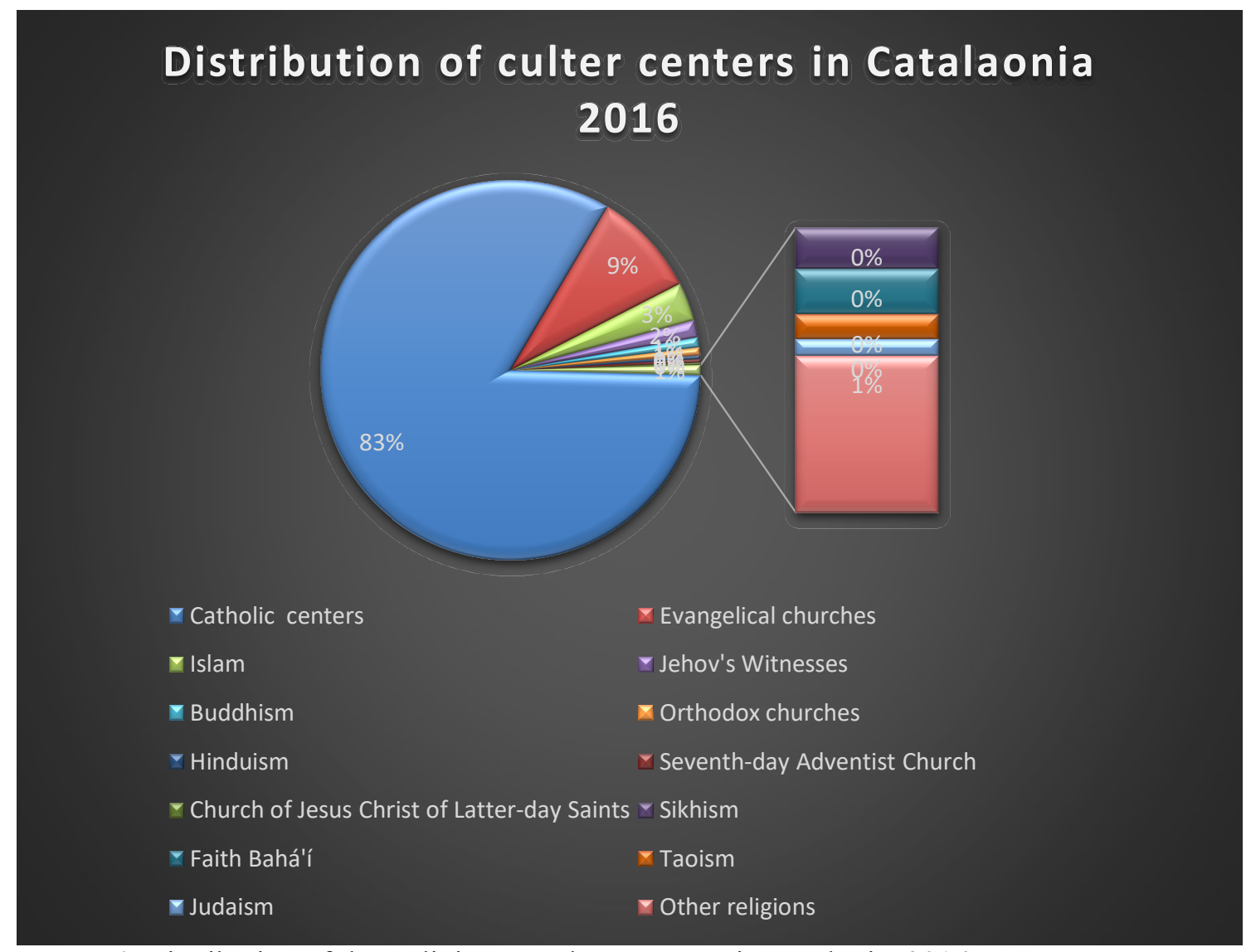

Figure 1 .Distribution of the Religious Coulters Centers in Catalonia. 2016

Although the Catholic religion is still the majority in the Spanish State, the current reality indicates trends towards the secularization. (Vendrell et al, 2004), Thus, in Spain the people who declare themselves ascribed to non-religious conscience has moved from $8 \%$ in 1978 to $25 \%$ in 2013 . In Catalonia this percentage of non-religious conscience arrives at $40 \%$.

Religious diversity must be understood as an opportunity to prevent possible factors of values and interests (Generalitat de Catalunya, 2013) or as a possibility of mutual enrichment and renewed and profound coexistence forereach a new interreligious sensitivity. (Torradeflot, 2011) Thus, is necessary to manage this religious diversity through interreligious dialogue. According to Santiago and Corpas (2012), interreligious dialogue implies a willingness to question one's own ideas in light of those of the rest; allowing mutual enrichment and transformation among the participants' dialogue. Dialogue implies respectful exchange with open-minded perspectives between groups and people with diverse cultural, religious and linguistic legacies (Elósegui, 2009). The management of diversity and interreligious dialogue should be framed in a model of secularism to accommodate the religious plurality based on mutual recognition (Coll 2012). This plurality is located at the public sphere, being understood as the spaces where civil society interacts. 
This paper emphasizes the challenge of the address of the religious diversity in our secular societies from the educational framework. Analyzing which attitudes have future socio-educational agents towards this religious diversity, towards interreligious and intercultural dialogue, and towards the role of education in the management of this diversity. Specifically, it is proposed to respond to the following objectives:

- To diagnose the attitude of future socio-educational agents in terms of intercultural and interreligious dialogue.

- To identify elements related to these attitudes.

\section{Method}

In order to respond to the objectives, a diagnostic study was carried out, based on the survey method, about the attitudes of the students of Primary and Infant Teacher Training, Social Education, Social Work and Pedagogy. These students will be the future socio-educational agents who from the formal and non-formal scope can intervene from the intercultural and interreligious dialogue.

\section{Participants}

The target population of the study has been the last-year students of the degrees of Pedagogy, Social Education, Social Work and Teacher Training (taking into account that not all the universities mentioned teach the five degrees) of four Catalan public universities: University of Barcelona, Rovira i Virgili University, University of Lleida and University of Girona. The sample is represented by a total of 574 students of the course 2.014-2.015 (Table 1).

Table 1

Contingency table on the participant sample according to university and degree.

\begin{tabular}{|c|c|c|c|c|c|c|c|}
\hline & & & & Studies & & & \\
\hline & & Pedagogy & $\begin{array}{c}\text { Primary } \\
\text { Education }\end{array}$ & $\begin{array}{c}\text { Early } \\
\text { Childhood } \\
\text { Education }\end{array}$ & $\begin{array}{c}\text { Social } \\
\text { Education }\end{array}$ & Social Work & Total \\
\hline University & $\begin{array}{ll}\text { URV } & \\
& \%\end{array}$ & $\begin{array}{r}43 \\
7,5 \%\end{array}$ & $\begin{array}{r}38 \\
6,6 \%\end{array}$ & $\begin{array}{r}32 \\
5,6 \%\end{array}$ & $\begin{array}{r}1 \\
, 2 \%\end{array}$ & & $\begin{array}{r}114 \\
19,9 \%\end{array}$ \\
\hline & $\begin{array}{rr}\text { UdL } & \\
& \% \\
\end{array}$ & & $\begin{array}{r}76 \\
13,2 \% \\
\end{array}$ & $\begin{array}{r}2 \\
, 3 \% \\
\end{array}$ & & & $\begin{array}{r}78 \\
13,6 \% \\
\end{array}$ \\
\hline & $\begin{array}{ll}\text { UdG } & \\
& \% \\
\end{array}$ & $\begin{array}{r}2 \\
, 3 \% \\
\end{array}$ & \begin{tabular}{r|}
11 \\
$1,9 \%$
\end{tabular} & \begin{tabular}{r|}
3 \\
, $5 \%$ \\
\end{tabular} & $\begin{array}{r}2 \\
, 3 \% \\
\end{array}$ & $\begin{array}{r}8 \\
1,4 \% \\
\end{array}$ & $\begin{array}{r}26 \\
4,5 \% \\
\end{array}$ \\
\hline & $\begin{array}{ll}\text { UB } & \% \\
& \%\end{array}$ & $\begin{array}{r}79 \\
13,8 \%\end{array}$ & $\begin{array}{r}123 \\
21,4 \%\end{array}$ & \begin{tabular}{r|}
56 \\
$9,8 \%$
\end{tabular} & $\begin{array}{r}46 \\
8,0 \%\end{array}$ & $\begin{array}{r}52 \\
9,1 \% \\
\end{array}$ & $\begin{array}{r}356 \\
62,0 \%\end{array}$ \\
\hline Total & $\%$ & \begin{tabular}{r|}
124 \\
$21,6 \%$
\end{tabular} & $\begin{array}{r}248 \\
43,2 \%\end{array}$ & $\begin{array}{r}93 \\
16,2 \%\end{array}$ & $\begin{array}{r}49 \\
8,5 \%\end{array}$ & \begin{tabular}{r|}
60 \\
$10,5 \%$
\end{tabular} & $\begin{array}{r}574 \\
100,0 \%\end{array}$ \\
\hline
\end{tabular}




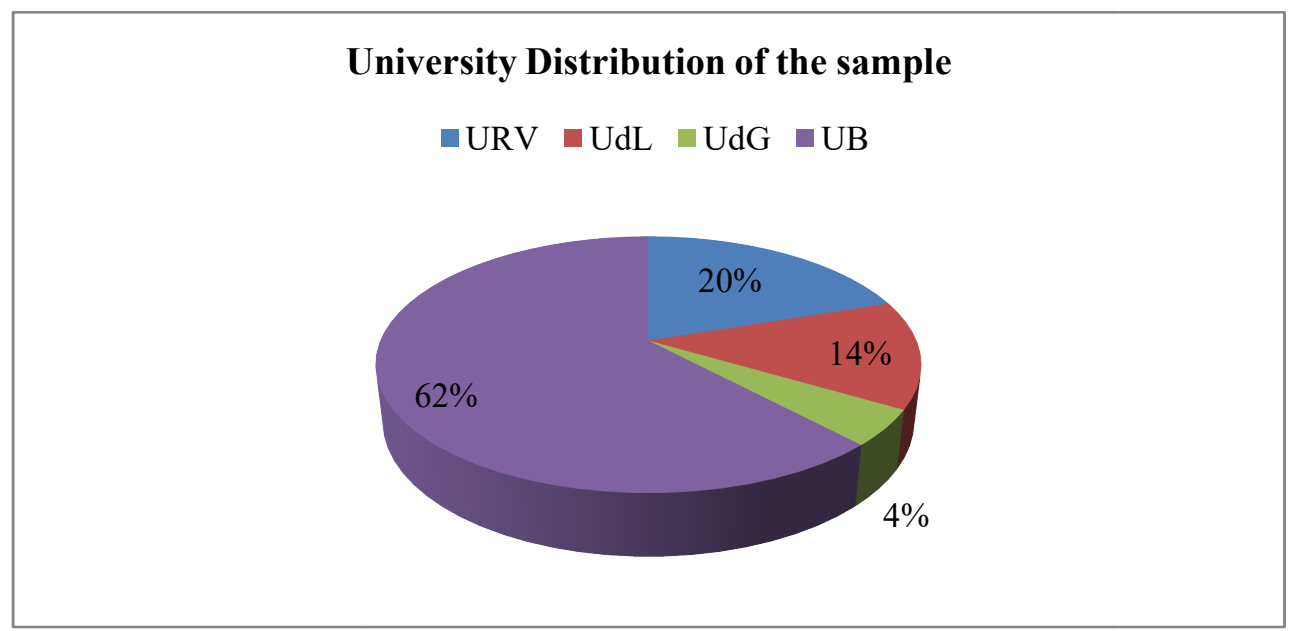

Figure 2 .Distribution of the universities participants

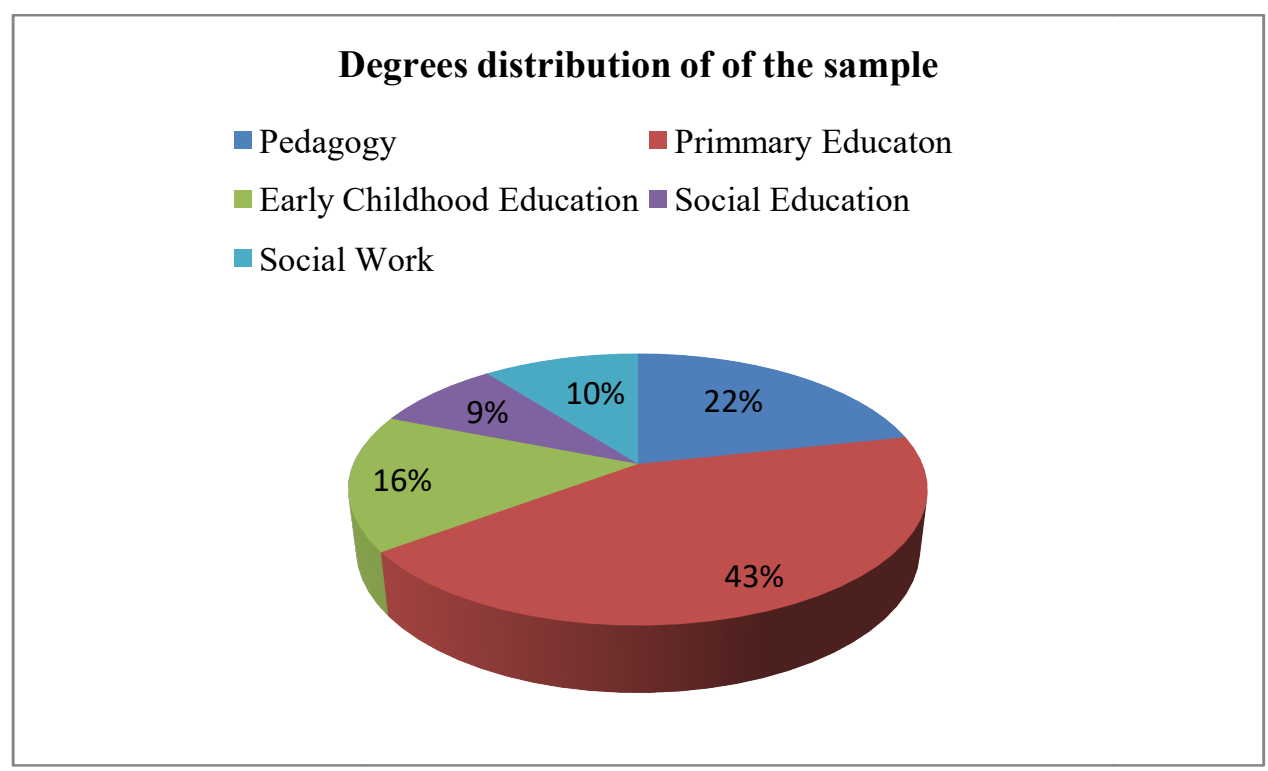

Figure 3.Distribution of the degrees participants

Considering that the whole of population of these degrees in these universities are 2550 students, this means a response rate of $22.5 \%$, and an error of 0.037 . The sample, just as the population is predominantly female, $84.8 \%$ is women versus $15 \%$ men. The average age of the students is 23 years old, although with some variability (high standard deviation of 4.86343). The vast majority of students were born in Catalonia $(92.7 \%), 4.7 \%$ in Spain and only $2.6 \%$ in the rest of the world.

\section{Instrument}

In the absence of measurement instruments that aim to measure attitudes to religious diversity and intercultural dialogue, especially from education, the "Scale of attitudes towards religious and cultural diversity" in education through intercultural dialogue was created. The theoretical foundations and dimensions of this scale were based on a precedent research. Then, a set of prescriptive needs were suggested by academic experts, representatives of public administration and entities. (Freixa et al., 2017). The validation of content through expert judgment allowed us to obtain a scale formed by 49 items, all considered adequate by the judges as a whole. This instrument was considered valid and reliable with an alpha Cronbach's $=0.906$. 
Table 2

Specifications of the Scale of attitudes towards religious and cultural diversity. (Freixa et al., 2017).

\begin{tabular}{|c|c|c|}
\hline DIMENSION & SUBDIMENSION & Items \\
\hline \multirow{4}{*}{ Religious diversity } & Factors that facilitate or difficult the religious diversity & 7 \\
\hline & $\begin{array}{l}\text { Discrimination: Of some religious, of women, fonts of } \\
\text { conflict }\end{array}$ & 6 \\
\hline & Presence at the public space & 8 \\
\hline & Total & 19 \\
\hline \multirow{3}{*}{$\begin{array}{l}\text { Intercultural and } \\
\text { Interreligious } \\
\text { Dialogue } \\
\end{array}$} & Concept of religion and interreligious dialogue & 9 \\
\hline & Factors that help the interreligious dialogue & 6 \\
\hline & 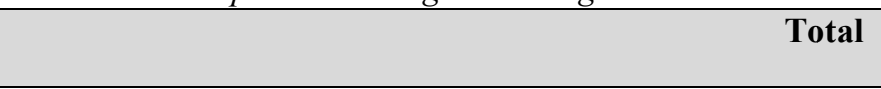 & 15 \\
\hline \multirow{5}{*}{ Role of Education } & Formal Education & 8 \\
\hline & Others Socio educative agents & 3 \\
\hline & Higher Education of the futures Socio educative agents & 4 \\
\hline & Total & 15 \\
\hline & Total Scale & 49 \\
\hline
\end{tabular}

\section{Results}

\section{General Over View about the Religion}

Near the half of the students declared themselves believers (39.3\%). Only the $17 \%$ of the participant student thought that there are some religions better than others one, but the $79 \%$ thought that there are religions that are more closed to interreligious dialogue than others.

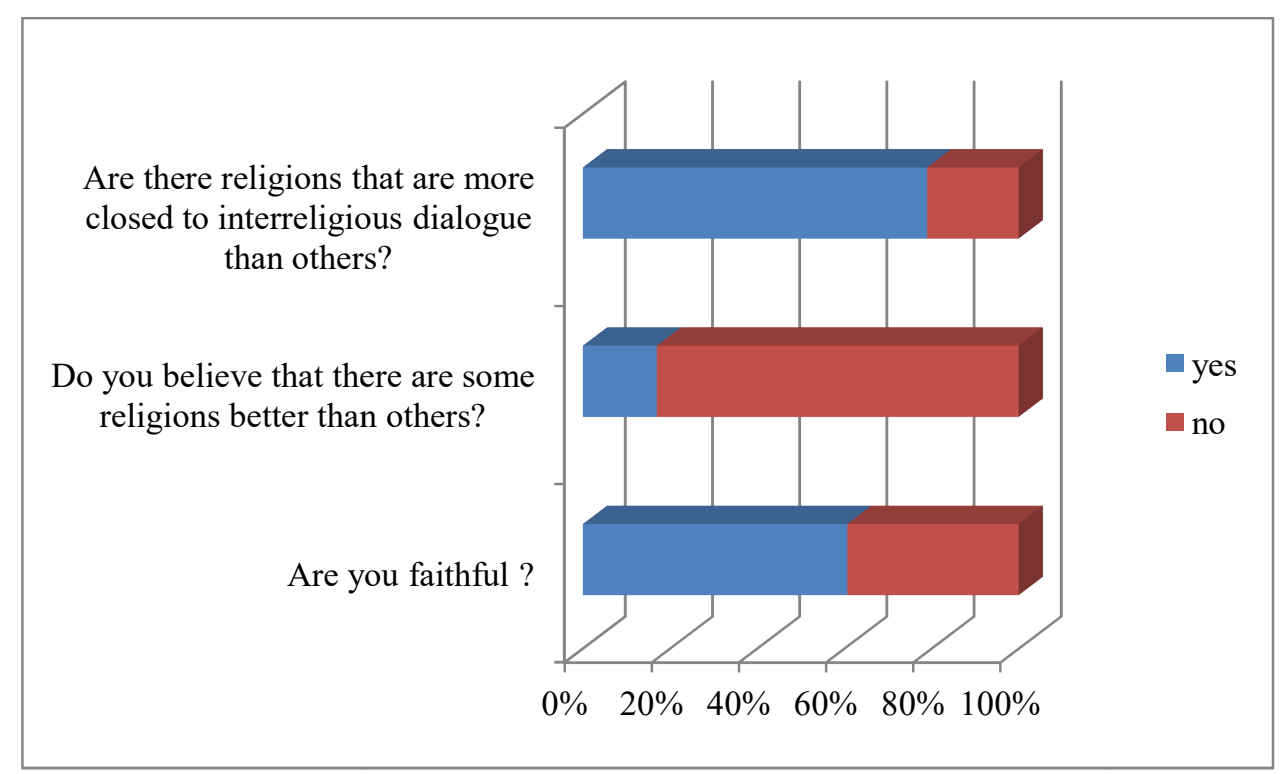

Figure 4. General over view about the religion

\section{The University Education}

Although $49.1 \%$ of the students stated that they had experienced some kind of religious diversity in the socio-educational sphere (for example, in university internships), only $14.6 \%$ had studied some religious content during their university 
studies. However, $46 \%$ said they had studied some content of religion in other training spaces.

$72 \%$ of the participants in the study stated that the university education received to promote intercultural and interreligious dialogue was insufficient. Similarly, 74\% believed it was important to be trained in these issues as a future socio-educational agent. Although $73 \%$ of students believed, there is no need to make the religion subject a compulsory material in the basic education.

\section{The Attitudes of Future Socio-Educational Agents}

The results obtained in the attitude scale show how the attitudes of the participants are quite low, especially regarding the role of education where an average of 21 points out of 75 was obtained. In other words, the students had an attitude little favorable to cultural and religious diversity; little favorable to interreligious dialogue and especially reluctant to the role played by the education plays in the management of religious and cultural diversity and the promotion of interreligious dialogue.

Table 3

Results related to attitudes.

\begin{tabular}{l|l|l|l|l|l|l|l|l|}
\hline & $N$ & $\begin{array}{l}\text { Theoretical } \\
\text { min }\end{array}$ & $\begin{array}{l}\text { Theoretical } \\
\text { intermediate }\end{array}$ & $\begin{array}{l}\text { Theoretical } \\
\text { max }\end{array}$ & Min & Average & SD \\
\hline Religious diversity & 74 & 19 & 57 & 95 & 35 & 93 & $\mathbf{6 7 , 9 8}$ & 9,35 \\
\hline $\begin{array}{l}\text { Intercultural and } \\
\text { interreligious } \\
\text { dialogue }\end{array}$ & 73 & 15 & 45 & 75 & 23 & 73 & $\mathbf{5 5 , 8 4}$ & 8,06 \\
\hline $\begin{array}{l}\text { The Role of } \\
\text { Education }\end{array}$ & 73 & 15 & 45 & 75 & 21 & 75 & $\mathbf{5 1 , 2 5}$ & 10,22 \\
\hline
\end{tabular}

\section{The University Degrees of the Future Socio Educational Agents}

According to the University's degree of the students, there are statistically significant differences in the scores obtained in the scale of attitudes toward cultural and religious diversity. In general, it is evident how the degrees of Social Education and Social Work have students with more favorable attitude to diversity, while the degrees of Pedagogy and Teacher Training have less favorable attitudes.

Table 4

Results related to the degrees implied in the research.

\begin{tabular}{|c|c|c|c|c|c|c|}
\hline & & & $\operatorname{dim} 1.1$ & $\operatorname{dim} 1.2$ & $\operatorname{dim} 1.3$ & Total Diversity \\
\hline \multirow[t]{6}{*}{ Bachelor } & \multirow[t]{2}{*}{ Pedagogy } & Average & 24,70 & 21,15 & 21,12 & 66,98 \\
\hline & & SD & 3,87 & 3,53 & 4,08 & 9,18 \\
\hline & \multirow{2}{*}{$\begin{array}{l}\text { Teacher in } \\
\text { Primary Ed. }\end{array}$} & Average & 25,36 & 21,44 & 20,90 & 67,70 \\
\hline & & SD & 4,01 & 3,23 & 4,02 & 9,13 \\
\hline & \multirow{2}{*}{$\begin{array}{l}\text { Teacher in } \\
\text { Early Ch. Ed. }\end{array}$} & Average & 24,30 & 20,86 & 20,56 & 65,72 \\
\hline & & SD & 3,66 & 3,44 & 3,84 & 8,84 \\
\hline
\end{tabular}




\begin{tabular}{|l|l|l|l|l|l|}
\hline $\begin{array}{l}\text { Social } \\
\text { Education }\end{array}$ & Average & $\mathbf{2 6 , 6 1}$ & $\mathbf{2 3 , 5 3}$ & $\mathbf{2 3 , 2 7}$ & $\mathbf{7 3 , 4 1}$ \\
\cline { 2 - 6 } & SD & 3,81 & 3,65 & 4,25 & 8,80 \\
\hline Social Work & Average & $\mathbf{2 5 , 5 5}$ & $\mathbf{2 2 , 2 3}$ & $\mathbf{2 2 , 5 0}$ & $\mathbf{7 0 , 2 8}$ \\
\cline { 2 - 6 } & SD & 3,43 & 4,16 & 4,72 & 10,00 \\
\hline \multirow{2}{*}{ Contrast Stats } & & $\mathrm{F}=3,661$ & $\mathrm{~F}=5,951$ & $\mathrm{~F}=5,506$ & $\mathrm{~F}=7,090$ \\
& & $\mathrm{p}=, 006$ & $\mathrm{p}=, 000$ & $\mathrm{p}=, 000$ & $\mathrm{p}=, 000$
\end{tabular}

Social Work and Social Education have the students with less unfavorable attitude toward cultural and religious diversity in general (total scale). Specifically, the Social Education students stand out for having the least unfavorable scores towards religious and cultural diversity in terms of considering the factors that favor or hinder religious diversity. Especially these data are statistically significant in comparison with the grades of Infant Education Teacher and Pedagogy. On the other hand, Social Education, again, has a less unfavorable student towards cultural and religious diversity, considering the aspects of discrimination that it entails (discrimination of certain religions as a source of conflict, discrimination against women ...). This difference is statistically significant especially when compared to the grades of Early Childhood Teacher, Pedagogy and Education Teacher. Social Work and Social Education have the students with a less unfavorable attitude toward the presence of cultural and religious diversity in the public space, especially if we compare the degree of Social Work with the degree, and Social Education with the rest of the grades.

\section{The Formative Experiences in the University}

The students whose have had experiences in cultural diversity, for example in their internship, have more favorable attitudes towards cultural and religious diversity, the interreligious dialogue and the role played by education. Students with experiences in religious diversity in the socio-educational area score statistically significantly higher than the one they have not had, in the totals of the three stairs and some dimensions.

The students with experiences in religious and cultural diversity are precisely those with more favorable attitude to diversity (especially in terms of their presence in public space), interreligious dialogue (especially considering the conceptual part of religion and dialogue) and that education plays a role in the management of religious and cultural diversity (especially regarding the role of formal education, as well as the importance of university education of socio-educational agents).

\section{Discussion}

This study has been one of the first diagnose made in the whole population of the socio educative students of a territory of the South of Europe. In times when the religious diversity is a key issue at the social and political level, after the jihadist terrorist attacks lived in Europe last years.

Some questions and issues arise from these results. A) The first one is the number of believers, in a generation of the XXI century that have grower in a secular society and have developed their compulsory education mostly in the public and secular system. 
b) Other interesting data is related with the experience of religious diversity; when the confession with most presence in the Catalan society is the Catholicism. In this moment is necessary remember that the average proportion of immigrated population in Catalonia is $13.78 \%$ (IDESCAT, 2017). If we considered this number as an approximated indicator of diversity, we can think that are biggest this level of interreligious experience that the theatrically expected based on the real diversity of the society. All of these data could be analyzed under the need of a transcendence and spiritual experience, the influence of the cultural traditions and media influence as well, a lie. For us is impossible to arrive to the true options. However, all of these tree options imply important effects that could be necessary to research in next studies.

Some of the conclusions of this study show the complex nature of the role played by the religion in the person and in the society. In countries like Catalonia, the religious issues are considered by the Educational Authorities as a private issue: The faith is a private issue, but most of the religious are played in a social community. This fact makes this private issue in a public one. This element can help to understand that the $72 \%$ of the students stated as insufficient the religious education received, but at the same times, they thought that this pertinent education ought to be offered in a way not compulsory.

The management of the space, the practices, the rights related with this private right, accepted by the Spanish Constitution is some else like a bridge, similar to the purpose of the Interreligious Dialogue or the Education of the Interreligious Competence. Thus, the need for training in the university system on these issues is identified, as expressed by the experts (UNESCO, 2005, Torradeflot, 2011, Lopez, 2012). The results obtained suggest that despite the lack of university training received and the attitude of the future socio-educational agents, their needs are assessed given the formative search of this done in other spaces and the presence of these contents in their daily experience both formative ( external practices) or personal.

These data highlight the importance that the students of the different universities give to the contents on religious diversity and intercultural and interreligious dialogue, in spite of their little curricular presence. We believe these results have relation with a concept of religious education close to the Substitution Model of Knitter (2008), which is what has traditionally been developed in traditional Catholic religious formation.

Another conclusion is that the territorial reality of Barcelona, more close to religious and cultural diversity, as well as the numerous initiatives for intercultural and interreligious dialogue that it carries out, can be a trigger for this lesser disadvantage of future socio-educational agents towards diversity both cultural and religious, especially in aspects of discrimination and presence in public space.

These results invite us to reflect more on the role of education and future educational agents in the degrees of Teacher Training and Pedagogy, without losing sight of the need for intervention in the rest of the grades that despite having somewhat less unfavorable scores towards diversity, they are still quite low scores. In this sense, our next research ought to advance the understanding of this faith identity, the feeling of interact in a interreligious scenario and the identification of the treats that broke this bridge of relation in the public sphere.

Of course, our research has several limitations, related with de meanings understood by the students and the researches. The interreligious issue, as all the cultural and social phenomena with an strong presence of subjective meaning and content is very sensitive to the fail and bias, even in a quantitative analysis as we have done in this study. 


\section{References}

Coll, M. (2012). "Laïcitat i diversitat religiosa".Revista de la cátedra sobre diversitat social de la Universitat Pompeu Fabra. Divèrsia,2, 3-35.

Elósegui, M. (2009). Políticas públicas y educación intercultural. En A J. Garay, G. Díaz, M.Elósegui y M. Sabariego.El diálogo intercultural en España: un requisito de la educación y cultura de Paz. (pp131-189) Madrid: Ministerio de Educación.

Estruch, J. (2014). "La diversitat religiosa a Catalunya".Revista de la cátedra sobre diversitat social de la universitat pompeu fabra.5, 3-12

Freixa, M., Vilà, R., Rubio, M.J. \& Belghirane, F. (2017). Los futuros pedagogos ante el hecho religioso. Estudio exploratorio en la Universidad de Barcelona. Revista Electrónica interuniversitaria de Formación del Profesorado, 20 (3), 195-207. DOI: http://dx.doi.org/10.6018/reifop.20.3.282501

Generalitat de Catalunya (2013). La diversitat religiosa en les societats obertes. Criteris de discerniment. Consell Assessor per a la diversitat religiosa. Barcelona. Generalitat de Catalunya, Departament de Governació i Relacions Institucionals. Barcelona.

Knitter, P.F. (Ed.). (1998). Pluralism and Oppression. Maryland: University Press.

López, M. (2012). Políticas europeas en relación con la formación en materia religiosa: la promoción del diálogo interreligioso y la educación intercultural. En J.L. Álvarez y M.A. Essomba (coords). Dioses en las aulas. Educación y diálogo interreligioso (pp61-84). Barcelona: Graó.

Santiago, M. y Corpas, C. (2012). Bases para el desarrollo de buenas prácticas de educación para la convivencia en la diversidad cultural y religiosa. En J.L Álvarez. y M.A Essomba, (coords.) Dioses en las aulas. Educación y diálogo interrelgioso . (pp123- 141) Barcelona: Grao.

Torradeflot, F. (2011). Religiones y pluralismo. Las vías del diálogo interreligioso en España. Madrid: Observatorio del Pluralismo Religioso en España.

Vendrell, E., Pont, J.F., CaneT, E., García-romeral, G., Griera, M.M., Martín,I.,Llorente,I; Funes,J; Stellà,S.J., Molina,V., Illa,O., Goberna,R., Villanueva,J., Panadero,H., Luque,S., Pont,A. y Faura,P. (2014).Informe Ferrer i Guàrdia. Aportacions per una societat laica. Barcelona. Fundació Ferrer I Guardia

Vendrell, E., Pont, J.F., CaneT, E., García-romeral, G., Griera, M.M., Martín,I.,Llorente,I; Funes,J; Stellà,S.J., Molina,V., Illa,O., Goberna,R., Villanueva,J., Panadero,H., Luque,S., Pont,A. y Faura,P. (2014).Informe Ferrer i Guàrdia. Aportacions per una societat laica.Barcelona. Fundació Ferrer I Guardia. Espais de Llibertat 